\title{
МАТЕМАТИЧНЕ МОДЕЛЮВАННЯ ПРУЖНОЇ ПІДВІСКИ КОЛІСНОГО ТРАНСПОРТНОГО ЗАСОБУ
}

\author{
Войтенко В.А., к.т.н., доцент \\ Одеська національна академія харчових технологій, м. Одеса, \\ Одеський національний політехнічний університет, м. Одеса
}

\begin{abstract}
Аннотація: Розглянуто схему заміщення пружної підвіски колісного транспортного засобу, запропоновано математичну модель, яка дозволяе оцінити плавність ходу колісного транспортного засобу $i$ вплив на нього параметрів основних конструктивних елементів пружної підвіски. У пакеті Matlab Simulink nеревірена працездатність запропонованої моделі. За результатами моделювання проведено аналіз частотних властивостей підвіски колісного транспортного засобу.

Annotation: The mathematical model of resilient pendant of transport vehicle, allowing to estimate the smoothness of car motion and influence the changes of parameter's of basic structural elements on him, is offered. The capacity of the offered model is tested in the Matlab Simulink package. On results the design the analysis of frequency properties of pendant of transport vehicle is conducted.
\end{abstract}

Ключові слова: плавність ходу, пружна підвіска, мотор-колеса, частотні властивості, амплітуда коливань, коефіцієнт жорсткості, коефіцієнт в'язкого тертя.

Вступ. Ідея застосування електродвигуна, інтегрованого в колесо колісного транспортного засобу (КТЗ), дозволяє обійтися без коробки перемикання передач, зчеплення, карданного валу, головної передачі, шарнірів рівної кутової швидкості. Це створює передумови для зниження ваги КТЗ, зменшення моменту інерції трансмісії, підвищення динамічних характеристик КТЗ при незмінній силі тяги, яку створюють колеса КТЗ. Відсутність механічної трансмісії звільняє місце для розташування пасажирів і вантажу. Крім того, застосування мотор-коліс дозволяє поліпшити керованість КТЗ в цілому, оскільки індивідуально керовані колеса можуть одночасно обертатися 3 різною швидкістю і у різних напрямах. В результаті можна підвищити активну безпеку руху КТЗ завдяки застосуванню більш складних алгоритмів керування кожним колесом при розгоні, гальмуванні і русі КТЗ в поворотах [1-4]. Також при застосуванні мотор-коліс стає можливою більш ефективна робота системи регенерації енергії при гальмуванні або при русі КТЗ в поворотах. В результаті цього створюються додаткові умови для економії палива, зменшення викиду вихлопних газів і підвищення екологічної безпеки КТЗ [7-10].

Стосовно недоліків, то до них, як правило, відносять більшу масу мотор-коліс в порівнянні 3 звичайними колесами. Це приводить до збільшення не підресореної маси КТЗ, що на думку експертів, збільшує вібрацію кузова, знижує плавність ходу, а також підвищує знос підвіски КТЗ.

Метою роботи є дослідження впливу не підресореної маси КТЗ на плавність його ходу. Для цього необхідно розробити математичну модель пружної підвіски КТЗ і провести дослідження її частотних властивостей.

Матеріали дослідження. Під плавністю ходу, як правило, розуміють сукупність властивостей, які забезпечують обмеження вібрації елементів шасі і кузова КТЗ на рівні, прийнятному для водія, пасажирів і вантажу. Одним 3 основних джерел виникнення вібрації в КТЗ є взаємодія коліс з нерівною дорогою. Виступи і западини, розташовані на поверхні дороги на відстані від 100 м до 0,10 м, називають мікропрофілем дороги. Вони є основною причиною, яка приводить до коливань КТЗ [5, 6].

Найпростішим показником, який дозволяє оцінити плавність ходу КТЗ є частота і амплітуда коливань кузова. Хорошій плавності ходу відповідає частота коливань в інтервалі від 1 Гц до 1,5 Гц. Основними пристроями та елементами, які захищають КТЗ, вантаж і пасажирів від надмірно великих динамічних зусиль, що діють на них 3 боку дороги є пружна підвіска і шини.

На рис.1 показана схема заміщення підвіски КТЗ, на якій позначено: $\mathrm{C}_{\amalg}-$ коефіцієнт жорсткості шини колеса; $\mathrm{b}_{ш}-$ коефіцієнт в'язкого тертя в шині; $\mathrm{C}_{\mathrm{Aморт}}$ - коефіцієнт жорсткості амортизатора колеса; $\mathrm{b}_{\mathrm{Aморт}}-$ коефіцієнт в'язкого тертя в амортизаторі колеса; $\mathrm{m}_{\mathrm{K}}$ - маса колеса і жорстко пов'язаних з ними елементів підвіски; $\mathrm{m}_{\text {Куз }}-$ маса кузова КТЗ, яка припадає на одне колесо; $\Delta \mathrm{h}$ - відхилення від нульового рівня дороги точки контакту шини колеса 3 дорогою.

Для розробки математичної моделі підвіски КТЗ будемо використовувати рівняння руху, одержані на базі рівняння Лагранжа 2-го роду

$$
\frac{\mathrm{d}}{\mathrm{dt}}\left(\frac{\partial \mathrm{W}_{\mathrm{K} \Sigma}}{\partial \dot{\mathrm{q}}_{\mathrm{i}}}\right)-\frac{\partial \mathrm{W}_{\mathrm{K} \Sigma}}{\partial \mathrm{q}_{\mathrm{i}}}=\mathrm{Q}_{\mathrm{i}}-\frac{\partial \mathrm{W}_{\Pi \Sigma}}{\partial \mathrm{q}_{\mathrm{i}}}-\frac{\partial \mathrm{A}_{\Sigma}}{\partial \mathrm{q}_{\mathrm{i}}},
$$


де i - порядковий номер узагальненої координати; q, $\dot{\mathrm{q}}$ - узагальнена координата і швидкість їі зміни; $\mathrm{W}_{\mathrm{K \Sigma}}-$ сумарна кінетична енергія механізму підвіски і кузова КТЗ; $\mathrm{W}_{\Pi \Sigma}$ - сумарна потенційна енергія механізму підвіски і кузова КТ3; $\mathrm{Q}_{i}$ - узагальнена сила, прикладена до механізму підвіски; $\mathrm{A}_{\Sigma}$ - сумарна енергія, яка витрачається на подолання сил опору, не врахованих в $\mathrm{W}_{\text {Пг }}$ i в $\mathrm{Q}_{\mathrm{i}}$.

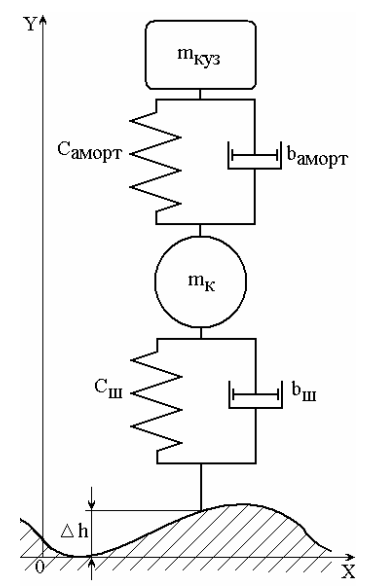

Рис.1. Схема заміщення підвіски КТЗ

На рис.2 показана розрахункова схема підвіски КТЗ в нерухомій системі координат 0ХY, горизонтальна вісь якої співпадає 3 нульовим рівнем дороги. На цій схемі прийняті наступні позначення: $\mathrm{R}_{\mathrm{K}}-$ вільний радіус недеформованого колеса; $\Delta \mathrm{R}_{\amalg}$ - деформація шини колеса в точці контакту іiі з дорогою; $\mathrm{L}_{\mathrm{Aморт}}-$ довжина не деформованого амортизатора колеса; $\Delta \mathrm{L}_{\mathrm{Aморт}}$ - деформація амортизатора колеса; $\mathrm{Y}_{\mathrm{K}}$ - висота осі обертання колеса над нульовим рівнем дороги; Үкуз - висота точки кріплення амортизатора до кузова КТЗ над нульовим рівнем дороги. Як узагальнені координати будемо розглядати $\Delta \mathrm{R}_{\amalg}, \Delta \mathrm{L}_{\mathrm{AмOPT}}$, а як збурюючий вплив $-\Delta \mathrm{h}$ або $\dddot{11}$ похідні.

На підставі рис. 2 можна записати

$$
\left\{\begin{array}{l}
\mathrm{Y}_{\mathrm{K}}=\mathrm{R}_{\mathrm{K}}-\Delta \mathrm{R}_{\text {Ш }}+\Delta \mathrm{h} ; \\
\mathrm{Y}_{\mathrm{KУз}}=\mathrm{R}_{\mathrm{K}}-\Delta \mathrm{R}_{\text {Ш }}+\mathrm{L}_{\mathrm{AMOPT}}-\Delta \mathrm{L}_{\mathrm{AMOPT}}+\Delta \mathrm{h} .
\end{array}\right.
$$

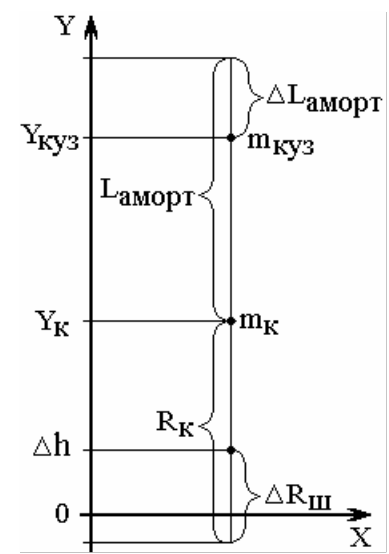

Рис.2. Розрахункова схема підвіски КТЗ

3 урахуванням того, що $\mathrm{R}_{\mathrm{K}}=$ const $\mathrm{i} \mathrm{L}_{\mathrm{Aморт}}=$ const, визначимо першу похідну системи рівнянь (2) за часом

$$
\left\{\begin{array}{l}
\dot{\mathrm{Y}}_{\mathrm{K}}=\Delta \dot{\mathrm{h}}-\Delta \dot{\mathrm{R}}_{\mathrm{W}} \\
\dot{\mathrm{Y}}_{\mathrm{Kуз}}=\Delta \dot{\mathrm{h}}-\Delta \dot{\mathrm{R}}_{\amalg}-\Delta \dot{\mathrm{L}}_{\mathrm{AMOPT}}
\end{array}\right.
$$

де $\dot{\mathrm{Y}}_{\mathrm{K}}, \Delta \dot{\mathrm{R}}_{\text {Ш }}, \dot{\mathrm{Y}}_{\mathrm{куз}}, \Delta \dot{\mathrm{L}}_{\text {Аморт }}, \Delta \dot{\mathrm{h}}$ - швидкість зміни даних величин.

Сумарна кінетична енергія маси колеса і маси кузова КТЗ разом з вантажем, яка припадає на одне колесо, в нерухомій системі координат ОХY визначається виразом 


$$
\mathrm{W}_{\mathrm{K} \Sigma}=\frac{\mathrm{m}_{\mathrm{K}}\left(\Delta \dot{\mathrm{h}}-\Delta \dot{\mathrm{R}}_{\mathrm{W}}\right)^{2}+\mathrm{m}_{\mathrm{Kу} 3}\left(\Delta \dot{\mathrm{h}}-\Delta \dot{\mathrm{R}}_{\text {Ш }}-\Delta \dot{\mathrm{L}}_{\text {АMOPT }}\right)^{2}}{2} .
$$

Сумарна потенційна енергія маси колеса і маси КТЗ, яка припадає на одне колесо, а також деформованих пружних елементів в системі координат 0ХY визначається виразом

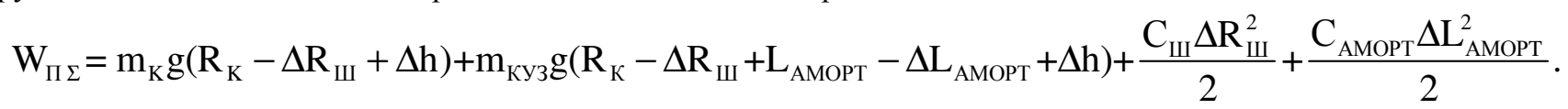

Сили опору при деформації шини визначаємо за виразом

$$
\mathrm{F}_{\mathrm{CW}}=\mathrm{a}_{\amalg}+\mathrm{b}_{\amalg} \Delta \dot{\mathrm{R}}_{\amalg}+\mathrm{d}_{\amalg} \Delta \ddot{\mathrm{R}}_{\amalg}
$$

де $\mathrm{a}_{ш}$ - постійна складова сили опору деформації шини; $\mathrm{b}_{\amalg}$ - коефіцієнт в'язкого тертя, що відображає залежність сили опору від швидкості деформації шини; $\mathrm{d}_{\amalg}$ - маса ділянок шини, які пересуваються при іï деформації.

Сумарна енергія, яка витрачається на подолання сил опору при деформації шини колеса

$$
\mathrm{A}_{\mathrm{C} \amalg}=\mathrm{F}_{\mathrm{C}} \Delta \mathrm{R}_{\amalg}=\left(\mathrm{a}_{\amalg}+\mathrm{b}_{\amalg} \Delta \dot{\mathrm{R}}_{\amalg}+\mathrm{d}_{\amalg} \Delta \ddot{\mathrm{R}}_{\amalg}\right) \Delta \mathrm{R}_{\amalg} .
$$

Силу опору, яка приводить до деформації амортизатора визначаємо за виразом

$$
\mathrm{F}_{\text {С АMOPT }}=\mathrm{a}_{\text {AMOPT }}+\mathrm{b}_{\text {АMOPT }} \Delta \dot{\mathrm{L}}_{\text {AMOPT }}+\mathrm{d}_{\text {АMOPT }} \Delta \ddot{\mathrm{L}}_{\text {АMOPT }} \text {, }
$$

де $\mathrm{a}_{\text {Аморт }}$ - постійна складова сили опору деформації амортизатора; $\mathrm{b}_{\text {Аморт }}$ - коефіцієнт в'язкого тертя, що відображає залежність сили опору від швидкості деформації амортизатора; $\mathrm{d}_{\mathrm{Aморт}}-$ маса елементів амортизатора, які пересуваються при його деформації.

Сумарна енергія, яка витрачається на подолання сил опору при деформації амортизатора

$$
\mathrm{A}_{\text {C АMOPT }}=\mathrm{F}_{\text {C АMOPT }} \Delta \mathrm{L}_{\text {АMOPT }}=\left(\mathrm{a}_{\text {АMOPT }}+\mathrm{b}_{\text {АMOPT }} \Delta \dot{\mathrm{L}}_{\text {АMOPT }}+\mathrm{d}_{\text {АMOPT }} \Delta \ddot{\mathrm{L}}_{\text {АMOPT }}\right) \Delta \mathrm{L}_{\text {АMOPT }} \text {. }
$$

Підставимо одержані вирази в рівняння (1) і після перетворень одержимо систему 2-х рівнянь

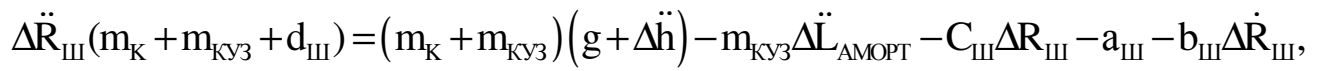

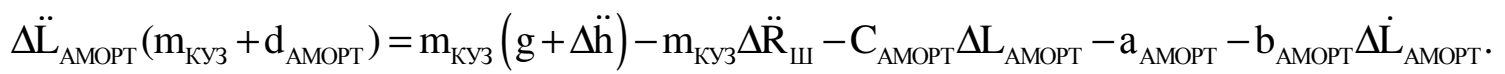

На підставі виразів (3) і (4) на рис.3 зображена структурна схема математичної моделі пружної підвіски. Як зовнішня дія розглядається прискорення зміни висоти дороги над його нульовим рівнем, а як вихідні величини довжина деформованого амортизатора $\left(\mathrm{L}_{\mathrm{Aморт}}-\Delta \mathrm{L}_{\mathrm{Aморт}}\right)$, висота осі обертання колеса над нульовим рівнем дороги $\mathrm{Y}_{\mathrm{K}}$, висота розташування точки кріплення амортизатора до кузова КТЗ над нульовим рівнем дороги $\mathrm{Y}_{\text {Куз. }}$

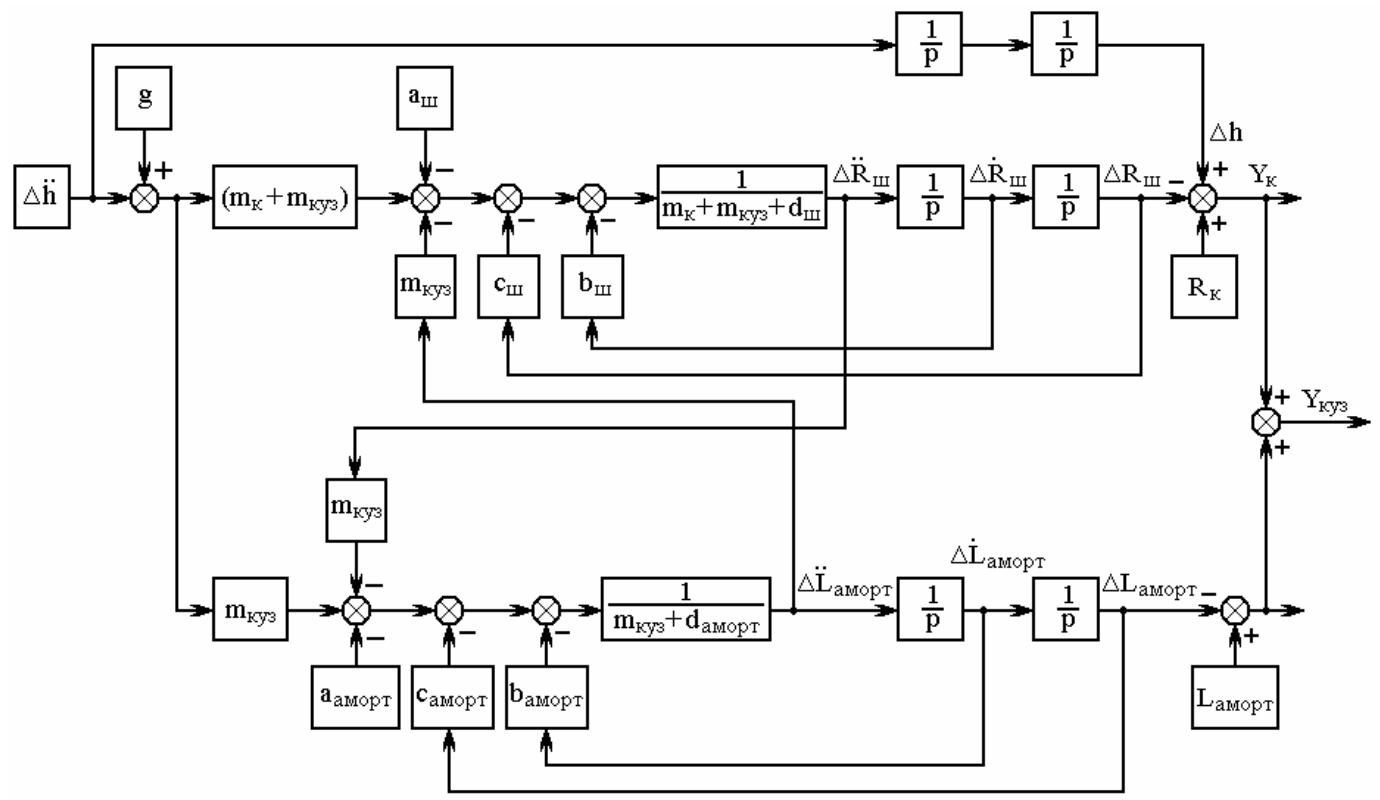

Рис.3. Структурна схема математичної моделі пружної підвіски 


\section{ТЕХНІЧНІ ЗАСОБИ І ІНФОРМАЦІЙНІ ТЕХНОЛОГІЇ У СИСТЕМАХ УПРАВЛІННЯ}

У загальному випадку мікропрофілем дороги $є$ набір горбів і западин різної величини, розташованих на різній відстані один від одного. Проте для проведення дослідження механізму підвіски будемо вважати, що мікропрофіль дороги має синусоїдальну форму

$$
\begin{gathered}
\Delta \mathrm{h}=\mathrm{Y}_{\text {Д }}\left[\sin \left(\frac{2 \pi}{\mathrm{S}_{\mathrm{T}}} \mathrm{S}_{\mathrm{ABT}}\right)+1\right], \\
\mathrm{S}_{\mathrm{ABT}}=\mathrm{V}_{\mathrm{ABT}} \mathrm{t},
\end{gathered}
$$

де $\mathrm{Y}_{\text {д }}$ - амплітуда синусоїди мікропрофіля дороги; $\mathrm{S}_{\mathrm{T}}$ - довжина періоду синусоїди мікропрофіля дороги, $\mathrm{S}_{\mathrm{ABT}}-$ поточне значення відстані, на яку пересувається КТЗ уздовж дороги; $\mathrm{V}_{\mathrm{ABT}}$ - швидкість пересування КТЗ; $\mathrm{t}-$ поточний час.

Після підстановки правої частини виразу (6) у вираз (5) одержимо

$$
\Delta \mathrm{h}=\mathrm{Y}_{\text {Д }}\left[\sin \left(\frac{2 \pi}{\mathrm{S}_{\mathrm{T}}} \mathrm{V}_{\mathrm{ABT}} \mathrm{t}\right)+1\right]=\mathrm{Y}_{\text {Д }}\left[\sin \left(2 \pi \mathrm{f}_{\mathrm{ABT}} \mathrm{t}\right)+1\right],
$$

де $\mathrm{f}_{\mathrm{ABT}}=\mathrm{V}_{\mathrm{ABT}} / \mathrm{S}_{\mathrm{T}}$ - частота вібрації, яку створює дорога, при русі КТЗ. KT3

На підставі (7) можна одержати вираз, що визначає прискорення вібрації, яке створює дорога, при русі по ній

$$
\Delta \ddot{\mathrm{h}}=\mathrm{Y}_{\text {д }}\left(\frac{2 \pi}{\mathrm{S}_{\mathrm{T}}} \mathrm{V}_{\mathrm{ABT}}\right)^{2} \sin \left(\frac{2 \pi}{\mathrm{S}_{\mathrm{T}}} \mathrm{V}_{\mathrm{ABT}} \mathrm{t}\right) .
$$

Як приклад розглянемо передню підвіску автомобіля ГАЗ-24-01 «Волга». Повна маса автомобіля $\mathrm{m}_{\text {авт }}=1825$ кг;

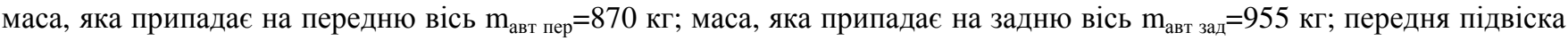
незалежна на поперечних важелях з циліндровими пружинами; маса передньої підвіски 101 кг. Коефіцієнт радіальної жорсткості шин $\mathrm{C}_{Ш}=200 \mathrm{\kappa H} / \mathrm{M}$, коефіцієнт в'язкого тертя шин, $\mathrm{b}_{\amalg}=15 \times 10^{3} \mathrm{H} /(\mathrm{m} / \mathrm{c})$. Маса колеса 3 шиною $\mathrm{m}_{\mathrm{K}}+\mathrm{m}_{\amalg}=21$ кг; Коефіцієнт в'язкого тертя амортизатора при його відбої $\mathrm{b}_{\mathrm{AмOPT1}}=4731 \pm 707 \mathrm{H} /(\mathrm{m} / \mathrm{c})$. Коефіцієнт в'язкого тертя амортизатора при його стисненні $\mathrm{b}_{\text {Аморт2 }}=1014 \pm 203$ H/(м/с) [11]. Пружини мають жорсткість $\mathrm{C}_{\mathrm{AMOPT}}=53000 \mathrm{H} / \mathrm{m} \mathrm{i}$ висоту $\mathrm{L}_{\text {Аморт }}=0,25 \mathrm{~m}$.

Відповідно до існуючих норм на покритті з булижника виступи і западини не повинні перевищувати 3,3 см [5]. У зв'язку з цим моделювання руху автомобіля проведемо для важчих умов, а саме для руху автомобіля по дорозі 3 мікропрофілем синусоїдальної форми з амплітудою $\mathrm{Y}_{д}=0,05$ м.

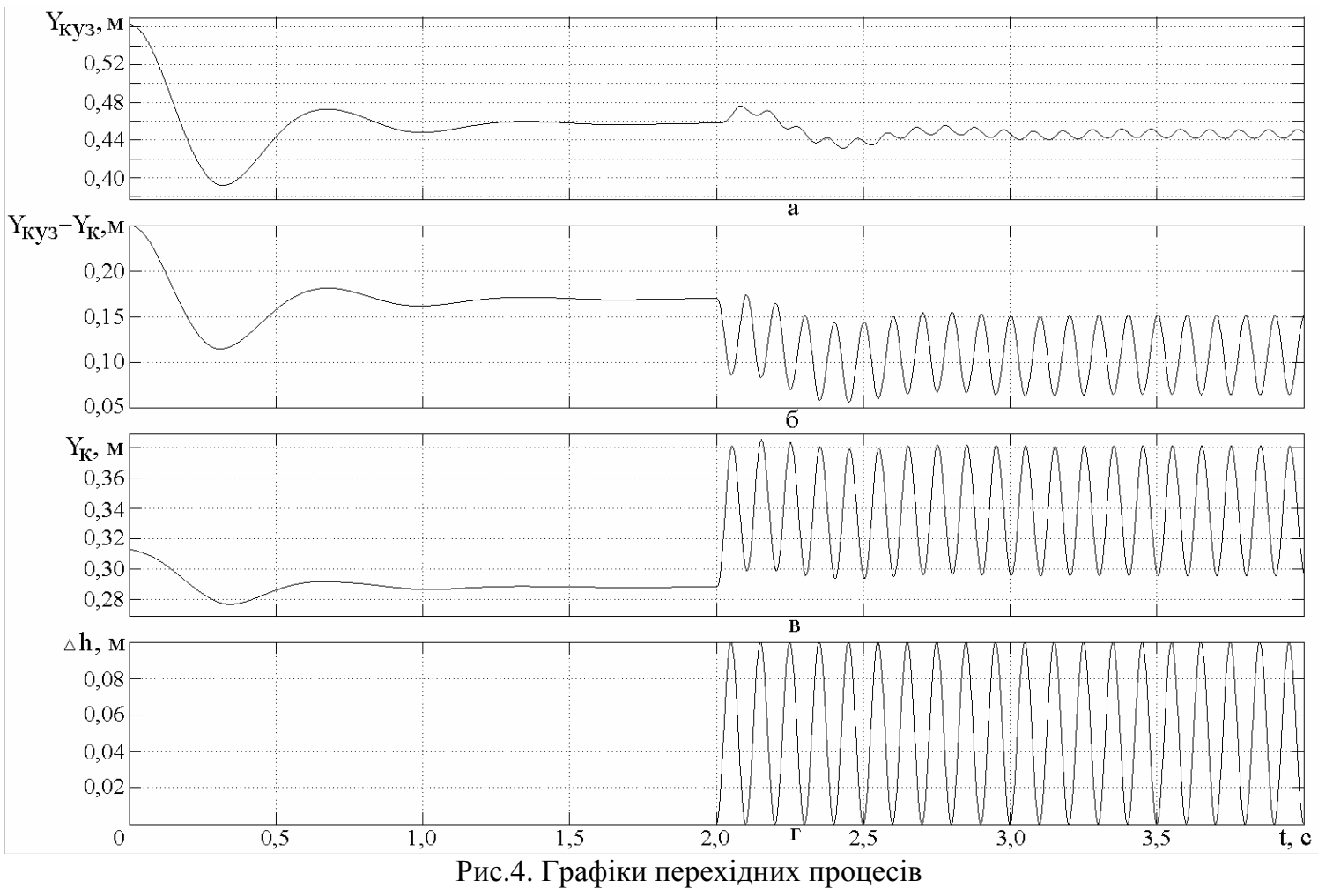


У пакеті Matlab Simulink була розроблена блок-схема запропонованої моделі. На рис.4 показані осцилограми роботи передньої підвіски автомобіля ГАЗ-24-01 «Волга», відповідні руху автомобіля протягом перших 2 секунд по

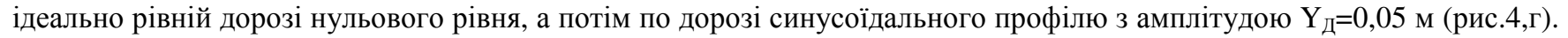
Виступи щодо нульового рівня дороги мають висоту 0,1 м і розташовані один щодо одного на відстані $\mathrm{S}_{\mathrm{T}}=1$ м. Автомобіль рухається із швидкістю $\mathrm{V}_{\mathrm{ABT}}=10 \mathrm{~m} / \mathrm{c}(36$ км/год).

Нульовому моменту часу відповідає не деформований стан шини колеса, амортизатора і пружини пружної підвіски. Потім на передню підвіску починає діяти сила тяжіння, яка приводить до деформації шини колеса на величину $\Delta \mathrm{R}_{\amalg}=2,48$ см (рис.4,в), амортизатора і пружини пружної підвіски $\left(\mathrm{L}_{\mathrm{AmopT}}-\Delta \mathrm{L}_{\mathrm{Aморт}}\right)=\left(\mathrm{Y}_{\text {Куз }}-\mathrm{Y}_{\mathrm{K}}\right)$ на 8,05 см (рис.4,б). В результаті висота точки кріплення амортизатора до кузова автомобіля щодо нульового рівня дороги ҮКуз зменшується на 10,53 см (рис.4,a). 3 рис.4 також видно, що період власних коливань автомобіля на пружній підвісці приблизно дорівнює 0,67 секунд (1,49 Гц).

При русі автомобіля по нерівній дорозі середній рівень осі обертання колеса підіймається за рахунок підвищення середнього рівня дороги на $\mathrm{Y}_{\text {Д}=0,05}$ м щодо їі нульового рівня (рис.4,г) і зменшення деформації шини на ділянках пониження дороги (рис.4,в). Робоча довжина деформованого амортизатора зменшується (рис.4,б) через те, що відповідно до паспортних даних амортизатора [11] коефіцієнт в'язкого тертя при його стисненні є меншим ніж при його розтиснені (відбої). Це приводить до зменшення висоти розташування точки кріплення амортизатора до кузова автомобіля над нульовим рівнем дороги, не дивлячись на підвищення іiї середнього рівня (рис.4,a).

3 рис.4 так само видно, що амплітуді коливань дороги в 5 см (рис.4,г) відповідає амплітуда коливань осі колеса дещо більше 4 см (рис.4,в), амплітуда зміни довжини деформованого амортизатора (Үкуз-Ү К) дещо більше 4 см (рис.4,б) і амплітуда коливань кузова автомобіля приблизно в 0,5 см (рис.4,a). Таким чином, амплітуда коливання кузова автомобіля приблизно в 10 разів менше за амплітуду коливань рівня дороги.
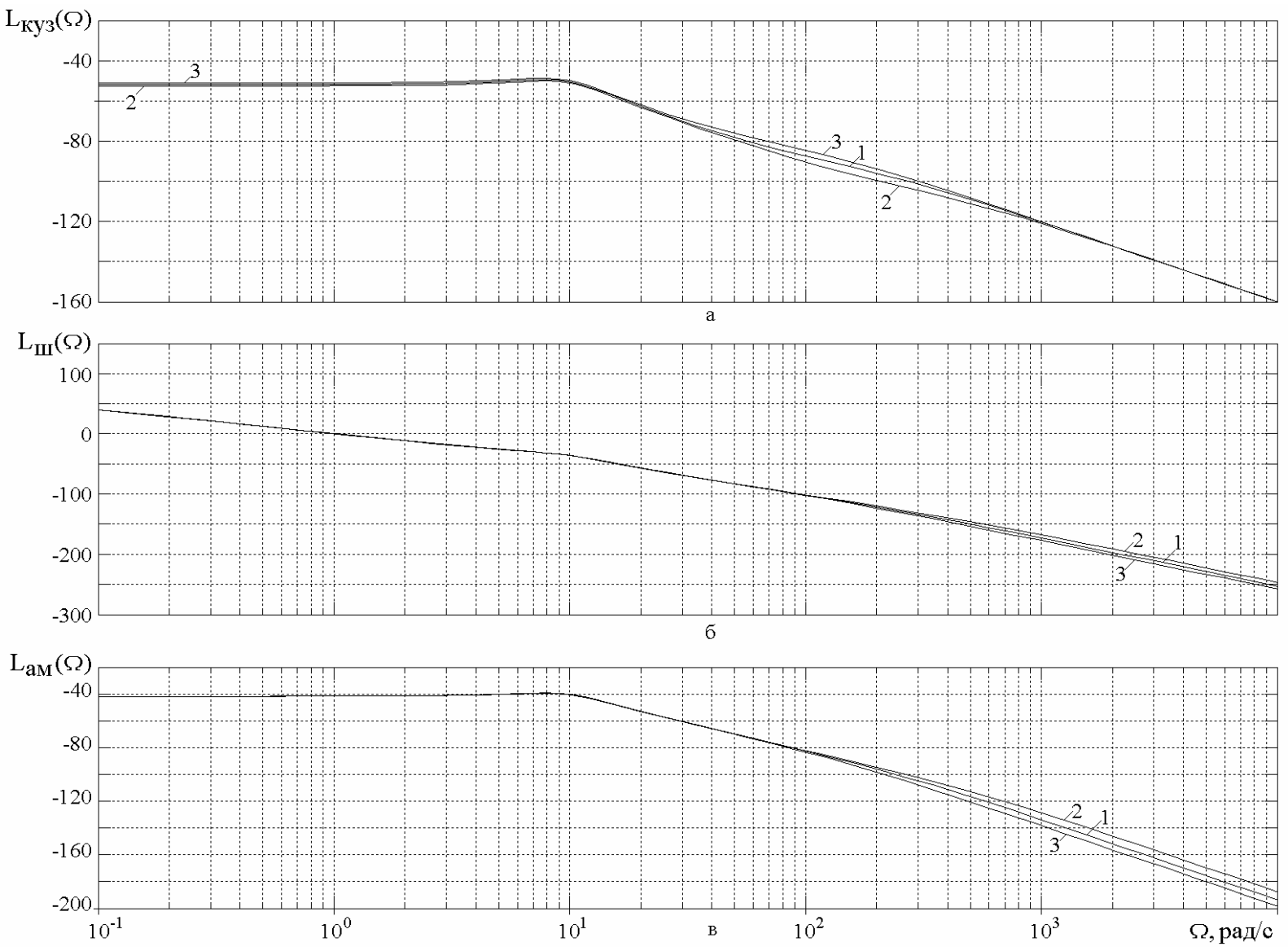

Рис.5. Логарифмічні амплітудно-частотні характеристики

Оскільки аналітичні вирази, що описують логарифмічні амплітудно-частотні характеристики даної системи, $є$ складними для аналізу, то частотні характеристики розраховувалися з використанням функціональних можливостей пакету Matlab. На рис.5 показано логарифмічні амплітудно-частотні характеристики, які відповідають структурній схемі математичної моделі, наведеної на рис.3. Вхідним сигналом є прискорення вібрації, яке створює нерівність 
дороги, а вихідними сигналами є положення точки кріплення амортизатора до кузова автомобіля над нульовим рівнем дороги $\mathrm{Y}_{\text {Куз }}$ (рис.5,a), деформація шини $\Delta \mathrm{R}_{\amalg}$ (рис.5,б), довжина деформованого амортизатора ( $\mathrm{L}_{\mathrm{AmopT}}{ }^{-}$ $\Delta \mathrm{L}_{\mathrm{AмOPT}}$ ) (рис.5,в). Крім того, для кожного вихідного сигналу бути розглянуто три значення сумарної маси не підресореної частини передньої підвіски автомобіля. Так, наприклад, для автомобіля ГАЗ-24-01, сумарна маса не підресореної частини передньої підвіски, яка припадає на одне колесо, дорівнює $(21+101 / 2)=71,5$ кг, і їй відповідає графік 1. В два рази меншій масі не підресореної частини передньої підвіски $(71,5 / 2=35,75 \kappa г)$ відповідає графік 2 , в два рази більшій масі не підресореної частини передньої підвіски (71,5×2=143 кг) відповідає графік 3 .

3 рис.5 видно, що резонансна частота автомобіля лежить в інтервалі від 9 рад/с до 10 рад/с $(1,43, \ldots, 1,59$ Гц) і практично не залежить від маси не підресореної частини передньої підвіски. При частоті коливань менше 10 рад/с амплітуда коливань деформації шини колеса (рис.5,б), і амортизатора (рис.5,в) практично не залежить від маси не підресореної частини передньої підвіски. Що стосується амплітуди коливань кузова (рис.5,a), то із збільшенням маси не підресореної частини передньої підвіски вона дійсно збільшується, але це збільшення невелике. Так при 4кратному збільшенні маси не підресореної частини підвіски амплітуда коливань кузова збільшується лише на 1,57 дБ (у 1,20 рази).

При частоті коливань більшій за 10 рад/с залежність амплітуди коливань деформації шини колеса, i амортизатора від маси не підресореної частини виявляється сильніше, але амплітуда цих коливань ослаблена в $100, \ldots, 1000$ разів в порівнянні з амплітудою коливань у області частот менших 10 рад/с. Що стосується амплітуди коливань кузова, то вплив маси не підресореної частини передньої підвіски в найбільшій мірі проявляється в діапазоні частот від 50 рад/с (8 Гц) до 500 рад/с (80 Гц). При 4-кратному збільшенні маси не підресореної частини передньої підвіски амплітуда коливань кузова збільшується на 6,67 дБ (у 2,15 рази), але при цьому амплітуда коливань кузова ослаблена в 100 разів в порівнянні з амплітудою його коливань у області частот менших за 10 рад/с.

\section{Висновки}

3 рис.5 видно, що резонансна частота досліджуваного автомобіля лежить в інтервалі $9, \ldots, 10$ рад/с $(1,43, \ldots, 1,59$ Гц), що відповідає хорошій плавності ходу, до якої прагнуть конструктори автомобілів. Це дозволяє зробити висновок про відповідність параметрів розробленої моделі реальним параметрам пружної підвіски автомобіля.

Крім того, на підставі ЛАЧХ, показаних на рис.5, можна стверджувати, що зміна маси не підресореної частини підвіски в 4 рази не оказує помітного впливу на плавність ходу автомобіля при незмінних значеннях їі жорсткості і демпфуючих властивостей. Тому застосування мотор-коліс, які збільшують масу не підресореної частини підвіски на 10-20 кг, не приведе до помітної зміни плавності ходу автомобіля.

\section{Литература}

1. Reimpell J. The Automotive Chassis: Engineering Principles. - Butterworth - Heinemann, 2001. -444 p.

2. Войтенко В.А. Система контроля тяги электротранспортного средства / Войтенко В.А., // Электротехнические и компьютерные системы - К.: Техніка. - 2012. - Вып. 08(84). - С. 7-11.

3. Вершинин Д. В., Войтенко В. А., Смотров Е. А. Некоторые особенности построения системы управления многодвигательного электротранспортного средства / Вершинин Д. В., Войтенко В. А., Смотров Е. А. // Електромашинобудування та Електро-обладнання - К.: Техніка. - 2010. - Вып. 75. - С. 12-21.

4.Автомобильный справочник фирмы Bosh/ пер. с англ. Г.С. Дугин, Е.И. Комаров, Ю.Ф. Онуфрийчук; - [2-е изд.]. - М.: ЗАО «КЖИ «За рулём»», 2004. - 992 с.

5. Литвинов А.С., Фаробин Я.Е. Автомобиль: Теория эксплуатационных свойств: учебник для вузов по специальности «Автомобили и автомобильное хозяйство» / А.С.Литвинов, Я.Е. Фаробин - М.: Машиностроение, 1989. - $240 \mathrm{c.}$

6. Раймпель Й. Шасси автомобиля: Амортизаторы, шины колёса./ Под ред. О. Д. Златовратского; пер. с нем. М.: Машиностроение, 1986. - 320с.

7. Cornel Stan. Alternative Antriebe für Automobile. Hybridsysteme, Brennstoffzellen, alternative Energieträger. 2. erweiterte Auflage./ Cornel Stan -Berlin Heidelberg: Springer, 2008. - 352 s.

8. Konrad Reif. Automobilelektronik. Eine Einführung für Ingenieure. 2., überarbeitete und erweiterte Auflage./ Konrad Reif- Wiesbaden: Friedr. Vieweg \& Sohn Verlag, 2007. - 688 s.

9. Harald Naunheimer. Fahrzeuggetriebe. Grundlagen, Auswahl, Auslegung und Konstruktion./ Harald Naunheimer, Bernd Bertsche, Gisbert Lechnerv - Berlin Heidelberg: Springer-Verlag, 2007. - 732 s.

10. Gerhard Babiel. Elektrische Antriebe in der Fahrzeugtechnik. / Gerhard Babiel - Wiesbaden: Vieweg+Teubner, 2009. - $198 \mathrm{~s}$.

11.http://www.eltop.ru/triton/offroad/AmoPlaza.html 